\title{
The Influence of Kaolinite - Illite toward mechanical properties of Claystone
}

https://doi.org/10.1515/geo-2019-0035

Received April 5, 2019; accepted July 19, 2019

\begin{abstract}
This study investigates the relationship between clay minerals (kaolinite and illite) and rock properties of the claystone, including both mechanical (cohesion, friction angle, stress, and strain) and physical properties (natural water content, void ratio, and wet density), belonging to Warukin Formation of Kalimantan, Indonesia. Mineralogical characteristics of these rocks were studied using petrological and X-ray diffraction techniques, whereas the mechanical and physical properties were tested by conducting uniaxial and triaxial tests. Relationship among the variables was determined using correlation coefficients. It was observed that the mineralogy of the rocks pose strong constraints on their engineering properties. The results showed that an increase in illite content decreases cohesion, friction angle, strength, and safety factor; and increases natural moisture content, void ratio, and wet density. Although illite content of these rocks was just about $10.8 \%$ of the total minerals, it has significantly contributed to the modification of physical and mechanical properties. In contrast, kaolinite did not have a significant impact; since the correlation between various parameters was significantly low (correlation coefficient was much less, <0.3). Therefore while selecting the materials for geotechnical engineering applications, illite emerges as a safer alternative to kaolinite, especially when its concentration is less than $10.8 \%$ of the total rock mass.
\end{abstract}

Keywords: Kaolinite, Illite, Mechanical properties, Physical properties, Warukin, Settlement

\footnotetext{
*Corresponding Author: Supandi Supandi: Padjadjaran University Sumedang, Jawa Barat, Indonesia,

E-mail: supandi@sttnas.ac.id

Zufialdi Zakaria: Department of Applied Geology, Faculty of Geological Engineering, Padjadjaran University, Indonesia

Emi Sukiyah, Adjat Sudradjat: Department of Geosciences, Faculty of Geological Engineering, Padjadjaran University, Indonesia
}

\section{Introduction}

The correlation between clays and mechanical characteristics of claystone has been studied by many researchers [1-3] but the effect of the type of clay minerals on mechanical properties of rocks is poorly understood. However, change in the physical properties of the clastic sedimentary rocks can have a profound influence on their mechanical properties. They can substantially jeopardize the strength of these rocks and thereby their suitability for various engineering applications. Therefore, the minerals, especially clay minerals, pose strong constraints on mechanical strength of such clastic sedimentary rocks. Nevertheless, only few, if any, reports have so far been available on the types of minerals affecting the mechanical properties of rocks. It has been known that the physical property of clay minerals is a major factor for engineering design related to the behavior changes of the mechanical characteristics [4]. Several studies on montmorillonite have been carried out with respect to its application to engineering purposes, in particular for civil construction [5, 6]. However, there are no detailed studies on kaolinite and illite clays in relation to geotechnical properties; whether or not both clays have an important role in engineering design.

The reduction in strength of soft clays causes a decrease in bearing capacity and excessive settlement [7]. Kaolinite does not respond to chemical modifications but Na-smectite is highly sensitive to the variation of the chemistry of the pore fluid [8]. Lime-clay reactions depend on several factors such as mineralogical composition of clayey soil, the quantity of lime employed for treatment, and moisture content of the soil [9]. The strength parameters such as cohesion and friction angle of sand with clay mixture increases along with the increase in clay content. The resulting mixture can generally be considered dense for $10 \%$ of clay and greater. The increase in cohesion and internal friction angle is attributed to cementation and particle to particle contact, respectively [10]. Additional lime increases strength of clay materials. Montmorillonite responds much more rapidly to lime stabilization than kaolinite [11]. Ple et al. [12] also studied the numerical analysis of flexural behavior of clay layer, but the clay 
types were not studied in greater details. Similarly, characterization of marine clays was determined, however their correlation with mechanical properties was not attempted by these authors.

Among the swelling type of clays, bentonite was found to be more effective in reducing residual friction angle than kaolinite [13]. The mechanical responses in kaolinite depend on aggregate to aggregate interaction rather than particle to particle interactions. The aggregates of kaolinite can be considered analogous to sand particles [14]. Microstructure of clays is also one of the crucial factors that must be considered. Determination of microstructure level refers to [15] as follows:

1. Level 0: the scale of elementary clay layers

2. Level 1: the scale for which the elementary clay layers are packed together to form a clay particle or an aggregate

3. Level 2: the submicrometer scale, often called the microscopic scale of porous clay composites constituted in a mixture of clay particles or aggregate

4. Level 3: often called the macroscopic scale, is the scale of that characteristic size, the submillimeter range

According to the microstructure levels, the typical clay at the study area was expected to have level 3, since the materials were dominated by about 50\% quartz. Illite is able to absorb more water compared to kaolinite, although much lesser than montmorillonite [16]. The rate of water absorption causes alteration of the mechanical characteristics of illite to become more responsive than kaolinite. Fabric in stratified clays in laboratory test depends on the type of mineralogy [17]. Type of clays affects axial strain and the peak axial strain increases when the distance with effective stress decreases [18]. The work of [19] has demonstrated that a degradation model for the shear modulus of soft clays corresponded to the following aspects: the number of cycles, the cyclic stress ratio, the loading frequency, and the plasticity index. All the aforementioned studies did not determine the effects of the type of clays. Hence, further investigation is required to determine the type of clays affecting the fabric of claystone, particularly the mechanical properties for geotechnical engineering purposes. Based on their structure, clay minerals can be divided into following 4 groups:

1. Kaolin ite (1:1)

2. Hydrous mica (2:1)

3. Montmorillonite $(2: 1)$

4. Chlorite (2:2)

\section{Materials and Method}

\subsection{Sampling and Mineralogical Characterization of Claystone}

The claystone was obtained from Kusan Block, Tanah Bumbu regency, South Kalimantan province, Indonesia (see Fig. 1). This rock was grey to black in color, characterized by high water content due to high water level (5-10 $\mathrm{m}$ from surface). Samples were taken from slope face of coal mine areas, and claystone type was selected on the basis of visual description. Generally, a coal deposit is associated with fine-grained clastic sedimentary rocks, especially claystone and sandstone. The claystone was sampled using an undisturbed tube with a diameter of $70 \mathrm{~mm}$ and $50 \mathrm{~cm}$ in length, and then the samples were wrapped immediately to maintain its properties. A total of 35 samples was collected from all claystone outcrops and shipped to laboratory for further analysis. Sampling and sample handling were carried out as per the procedure of ASTM [20]. Mineralogical composition of the claystone was determined using X-ray powder diffraction analysis (XRD). The results indicate predominance of quartz, followed by kaolinite and illite (see Fig. 2). The clay-sized quartz with monocristalline habit has high hardness. Quartz content being homogeneous across the samples, can be ignored. Therefore, changes in the mechanical properties of rocks are influenced solely by the composition of clay minerals and changes in the physical properties of rocks. So the current emphasis was given to the clay minerals and the physical properties of rocks. Identification of clay mineral is done with a view to study the effect of clay minerals on the mechanical properties of the rocks.

\subsection{Mechanical Characterization of Claystone}

From 35 claystone samples, each sample was characterized for its mechanical properties including triaxial test, uniaxial test, moisture content, and density. Triaxial test was carried out to examine the strength and stress-strain relationships of cylindrical specimen of undisturbed samples. This is an important test for determination of the strength of rock in three dimensions [20]. A cylindrical specimen of a diameter of $3.3 \mathrm{~cm}$ and height to diameter ratio of 2-2.5 was selected for this study. Intrinsic Mohr curve was obtained from the triaxial test result, consisting 


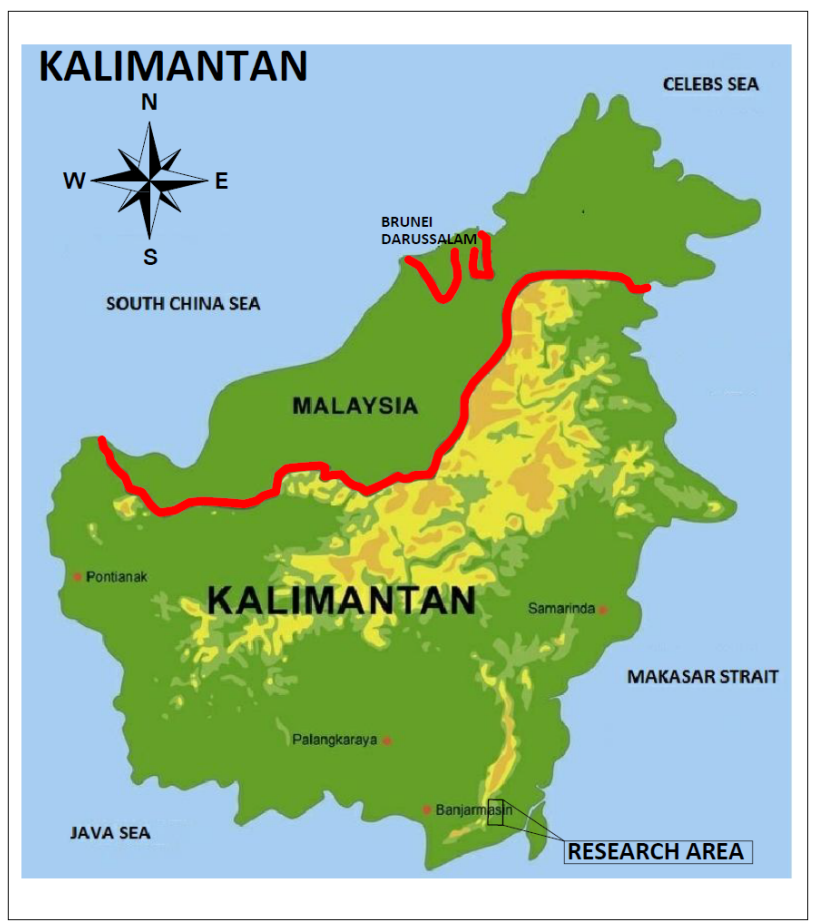

Figure 1: Study area in the Kusan Block, Tanah Bumbu Regency, South Kalimantan Province, Indonesia.

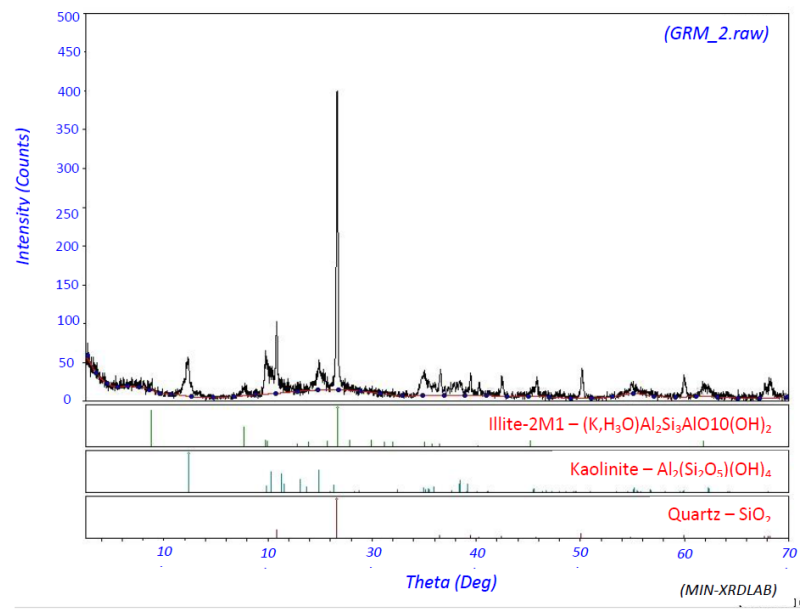

Figure 2: X-ray Diffraction pattern of the claystone used in this study.

of strength envelope, shear stress, friction angle, and cohesion.

Uniaxial test was conducted to determine the compressive stregth. A core sample was cut and ends were machine flat. Specimen sample was cylindrical having minimum diameter of $3.3 \mathrm{~mm}$ with height to diameter ratio of 22.5. The specimen was placed in a loading frame and compressed using uniaxial machine. Axial load was rapidly applied to the specimen and sustained. Deformation was monitored as a function of elapsed time. The uniaxial test results in the determination of compressive strength, elastic limit, modulus of elasticity, and Poisson ratio.

Similarly, moisture content test was determined in order to find out water content in the material mass. The water content is the percentage of ratio between water mass and specific gravity. The sample was oven dried at the temperature of $\sim 110^{\circ} \pm 5^{\circ} \mathrm{C}$ in a constant condition until the sample was completely dried. The weight loss due to drying (loss on ignition (LOI)) is considered to be water. In addition to moisture content test, rock density was also measured in this study, which is a measure of mass per unit volume. There is a relationship between the density and strength of the rock as well as the void ratio. The higher the density, stronger the rock, and lower the void ratio. In addition, void ratio is the differential equation resulting from the water content calculation. Void ratio reflects the comparison of the void volume of the rock mass to the total volume of the rock mass, where void volume is expressed in percentage. The greater the void volume, greater is the pore volume in the rock mass. The void volume in the rock mass causes water or air to fill the pore, so that the pore pressure will increase and eventually rock strength will decrease.

\section{Results and Discussion}

To obtain a relationship between clays (in this case illite and kaolinite) and the mechanical and physical properties; scatter diagrams were constructed by plotting the clay content against the mechanical and physical properties, and their correlation coefficient $(\mathrm{R})$ was computed. In principle, varying degrees of correlation are then represented by coefficients ranging from zero to 1 in either direction as follows: 0-0.19 (very low correlation), 0.2-0.39 (low correlation), 0.4-0.69 (medium correlation), 0.7-0.89 (strong correlation), 0.9-1 (very strong correlation) [21]. In other words, a coefficient of 1 indicates a perfect correlation between two variables and a coefficient of zero suggests a complete lack of correlation.

\subsection{The Relationship Between Kaolinite - Illite and Physical Properties}

A correlation between claystone physical properties (here natural water content) and illite or kaolinite content is given in Fig. 3. A strong correlation existed between natural water content and illite content $(R=0.8284, y=$ 
$\left.6.3144 \mathrm{e}^{0.0283 x}\right)$, whereas there is significantly lower correlation between natural water and kaolinite contents $(\mathrm{R}$ $=0.2544)$. This indicates that illite might have strong influence on physical properties of the claystone. For illite clays, $1 \%$ increase in illite content leads to $4 \%$ increase in water content. Such increase in water content results in decrease in rock mechanical properties [22], therefore an increase in water content under this study may reduce the rock mechanical properties due to pore pressure. It is also known that $1 \%$ increase in water content decreases cohesion and hardness of the rocks (1 KPa each and a 1\% decrease in friction angle).

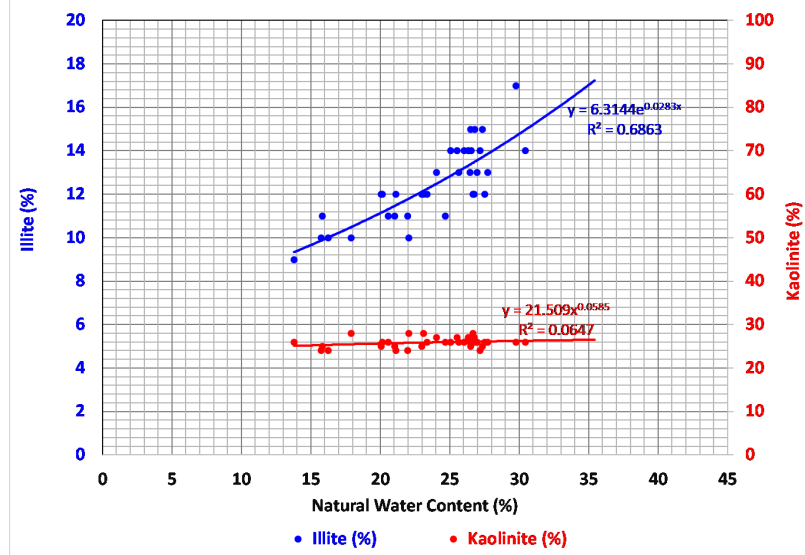

Figure 3: The relationship between natural water content (\%) and the illite content or kaolinite content.

In case of physical properties, a strong negative correlation was observed between the wet density and illite $\left(\mathrm{R}=-0.8087, \mathrm{y}=38.617 \mathrm{x}^{-1.789}\right)$, whereas negligible correlation with kaolinite $(\mathrm{R}=-0.2015)$ (see Fig. 4). This indicates that $1 \%$ increase in illite content results in substantial decrease in wet density $\left(0.1 \mathrm{~kg} / \mathrm{cm}^{3}\right)$. The relationship between these variables is an important parameter for geotechnical engineering design.

\subsection{The Relationship Between Kaolinite - Illite and Mechanical Properties}

The relationship between cohesion value and illite or kaolinite content in claystone (see Fig. 5) was tested. It was observed that a strong negative correlation exists between cohesion and illite $\left(\mathrm{R}=-0.8728, \mathrm{y}=71.117 \mathrm{x}^{-0.521}\right)$, but not so with kaolinite $(R=-0.2766)$. The inverse proportionality indicates that greater the illite content, the lower will be the cohesion $(\mathrm{kPa})$. From this study, it was observed

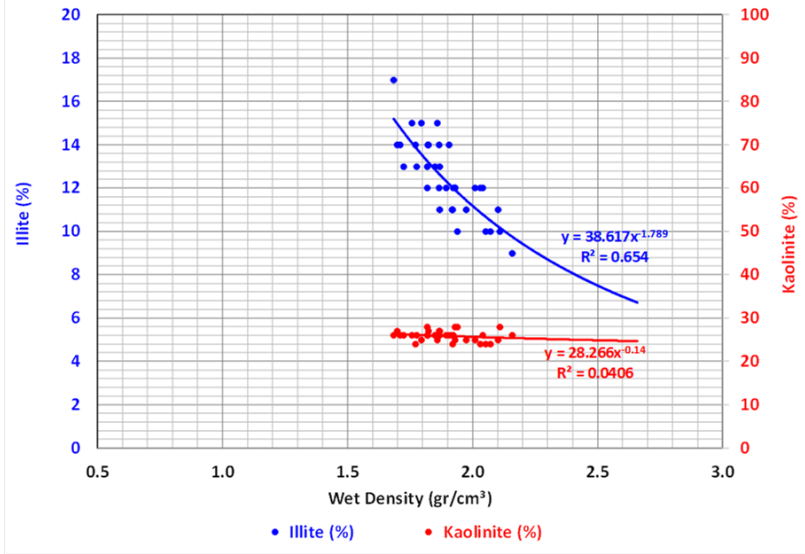

Figure 4: The relationship between wet density $\left(\mathrm{kg} / \mathrm{cm}^{3}\right)$ and the illite / kaolinite content.

that the illite content (8-15\% of the total mineral composition) corresponds to $\sim 20-50 \mathrm{kPa}$ of cohesion value. However, when the illite content was $>11 \%$, there was no association, and therefore no correlation between the two variables. About $1 \%$ increase in illite content is equitable to about $4 \mathrm{kPa}$ increase in the cohesion value. On the contrary, when the illite content was less than $11 \%, \sim 1 \%$ increase in illite content led to $\sim 8 \mathrm{kPa}$ increase in cohesion value. Therefore, in engineering application, concentration of illite clay should be considered while selecting the material for embankment. The illite percentage in the claystones should be less than $11 \%$. This makes illite clay as a key parameter for change in the mechanical properties of the rocks, particularly cohesion value.

Changes in claystone cohesion values are not affected by illite content alone, but also due to changes in physical properties such as changes in water content. It can be demonstrated that at the constant illite content, cohesion value decreases of claystone decreases due to water content, which forms identic patterns on the discrimination diagram (see Fig. 6). Therefore, $\mathrm{F}$ test regression is carried out on several variables that influence changes in cohesion value. Statistical test shows that every changes in cohesion value is affected by $34 \%$ water content and $18 \%$ illite content.

Another mechanical property affecting engineering applications is the friction angle (Phi); which is measured as the ability of a unit of rock or soil to withstand a shear stress. A strong negative correlation was observed between the friction angle and illite concentration $(\mathrm{R}=$ $-0.8876, y=36.6 \mathrm{x}^{-0.389}$ ), and a poor correlation was observed between the friction angle and kaolinite concentration $(\mathrm{R}=-0.2830)$ (see Fig. 7). It was observed that when illite content was $>11 \%$, the value of the friction 


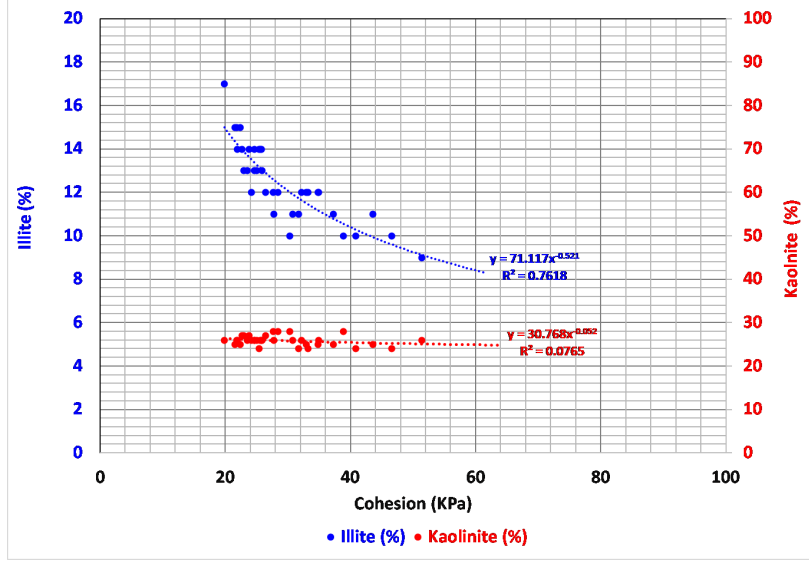

Figure 5: The relationship between the cohesion and the illite / kaolinite content.

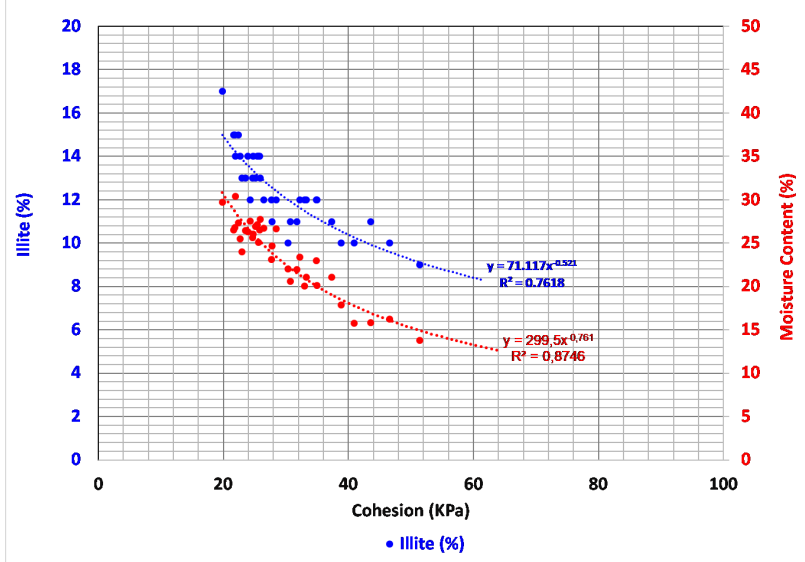

Figure 6: The relationship between the cohesion and the illite content as well as moisture content.

angle was not significant. However, when illite clay content was $<11 \%$, the friction angle $\left(3 \sim 6^{\circ}\right)$ increases significantly. In addition to friction angle, the strength $(\mathrm{kPa})$ of the claystone was also determined (see Fig. 8). The results have indicated that there is a negative correlation between strength of material and the percentage of illite. That is, decrease in illite clay content increases the strength $(\mathrm{R}=$ $\left.-0.8879, \mathrm{y}=25.486 \mathrm{x}^{-0.168}\right)$. In contrast, a poor correlation exists between the strength and kaolinite clay content ( $\mathrm{R}=-0.2007)$, indicating that the concentration of kaolinite has negligible role in mechanical properties of the host rock. It was observed that the illite content of $>10.8 \%$ has raised the strength of the material to $4 \mathrm{kPa}$, whereas that of $<10.8 \%$ increased the strength of $8 \mathrm{kPa}$. Illite also has strong correlation with axial strain $(\mathrm{R}=-0.7085, \mathrm{y}=$ $23.41 \mathrm{e}^{-0.14 x}$ ) (see Fig. 9). An increase in illite concentration resulted in an increase in axial strain by $0.4 \%$. Therefore, these results reiterate that illite clay played an important role in controlling physical and mechanical properties of the claystone, which is employed as an embankment material for any engineering purpose.

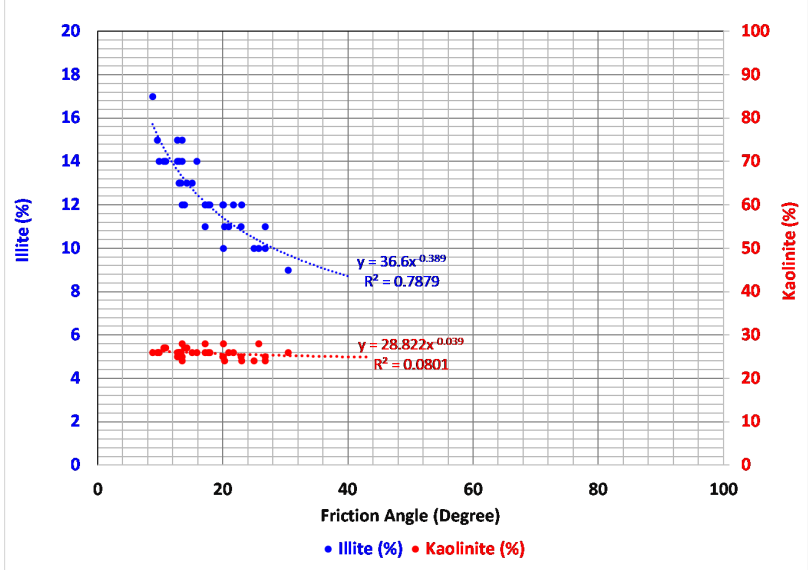

Figure 7: The relationship between the friction angle $\left(^{\circ}\right)$ and the illite or kaolinite content.

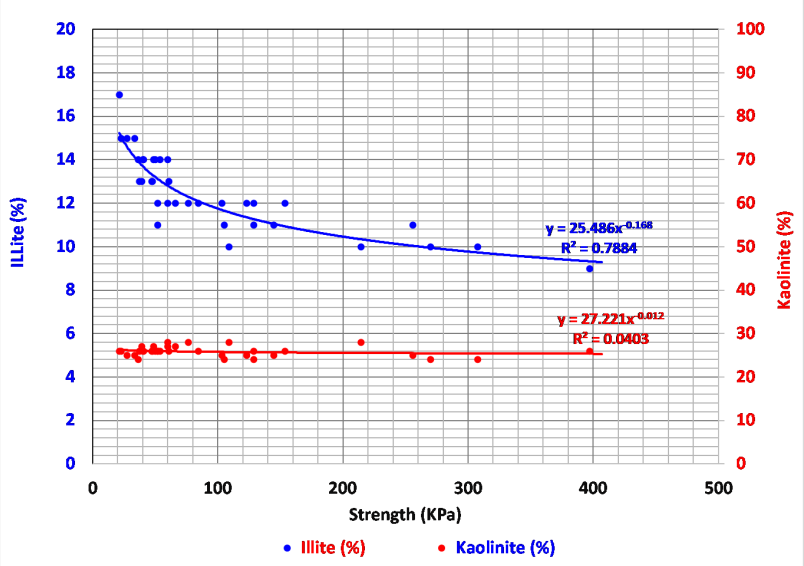

Figure 8: The relationship between the strength $(\mathrm{kPa})$ and the illite or kaolinite content.

\subsection{Role of Illite in Engineering Analysis \& Road Settlement}

The engineering analysis was also performed for road construction and hauling with soil embankment dominated by clay materials. The analysis was carried out at variable concentrations of illite such as 15\%,10.8\%, and 8.5\% (see Fig. 10). The mechanical properties that were tested 


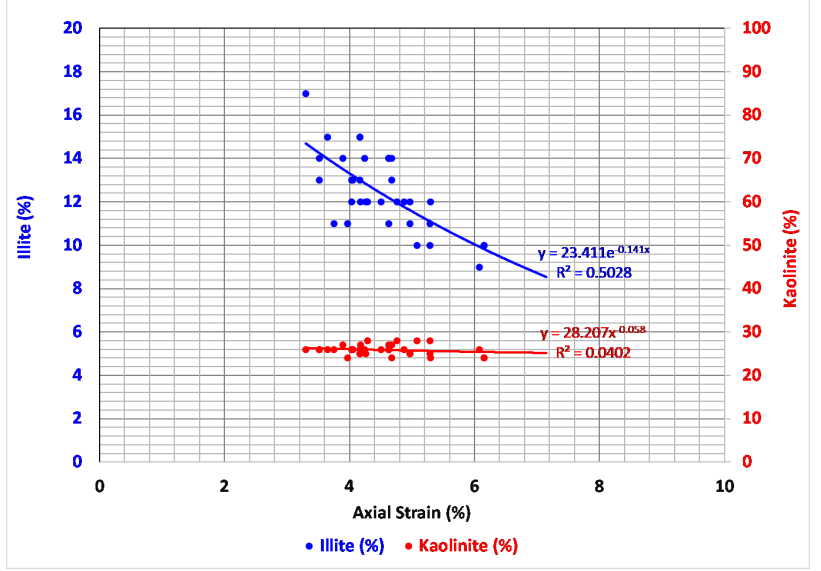

Figure 9: The relationship between the axial strain (\%) and the illite or kaolinite content.

includes cohesion value and friction angle by using claystone as an embankment base. In this case, the embankment analysis was conducted on stability value to get the value of safety factor and the value of vertical settlement on the road condition with a truck load of $\sim 40$ ton.

It was observed that the decrease in illite content results in increasing mechanical properties as important aspects in engineering analysis. It was shown in the engineering analysis that the decreased illite content was strongly correlated with an increase in safety factor values. Moreover, a very strong positive correlation existed between illite content and settlement value. On the road construction and hauling operations, the illite content should be controlled (see Fig. 11). It was observed that the roads constructed without consideration of illite content resulted in poor road quality (see Figs. 11(a)-11(b)). In the present study area, where clay minerals were the major constituents, layers having lower amount of illite produced good quality roads (see Figs. 11(c)-11(d)). Therefore the present study brings forth that the road construction of hauling could be undertaken by layering with materials containing a low amount of illite clay to acquire the better road quality.

\section{Conclusion}

Illite has a very strong relationship with the mechanical and physical characteristics of the claystones, whereas kaolinite remains neutral. The increased illite content corresponds to the decrease in cohesion, friction angle, strength, and axial strain of the claystone. The increased illite content also has significant effect on increase in wa-
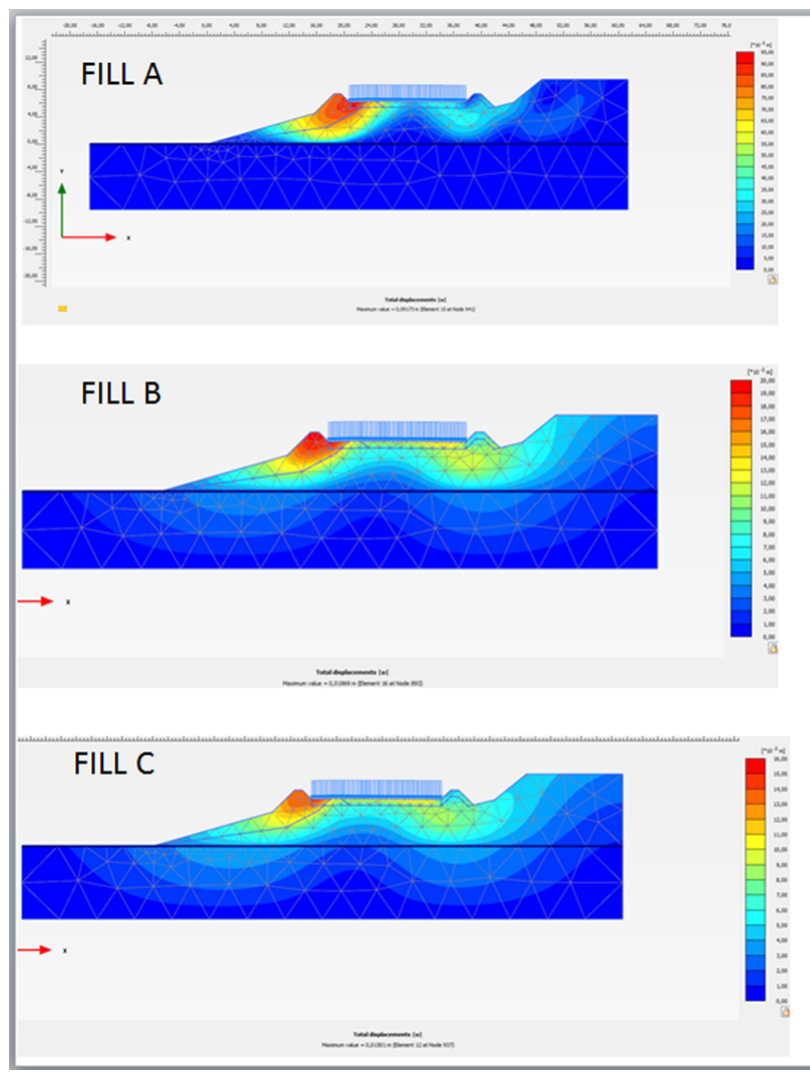

Figure 10: Images of road construction site showing hauling with soil embankment dominated by clay materials. Varying illite content of $15 \%$ (fill A), $10.2 \%$ (fill B), and $8.5 \%$ (fill C) are shown.

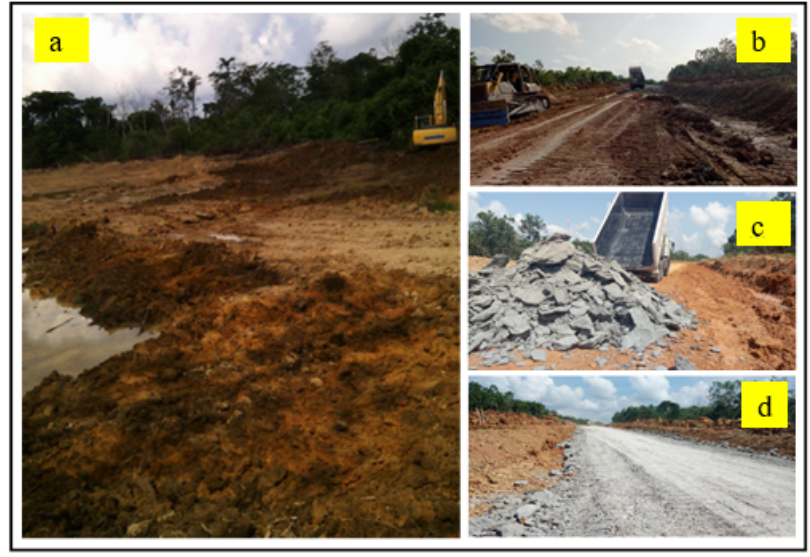

Figure 11: Preparation of connecting road from pit to phase 4 "layering road".

ter content, void ratio, and wet density. An increase in water content and void ratio is strongly correlated with the decreased mechanical characteristics of the claystone. In contrast, the kaolinite content is not correlated with cohesion, friction angle, strength, and axial strain; as well as water content, void ratio, and wet density. Engineer- 
ing analysis has shown that the increased value of safety factor and settlement are strongly associated with the percentage of illite: the greater the illite content, the higher the settlement value and lower the safety value. It is suggested here that while selecting the construction materials involving clays, more attention should be paid to illite content; which should be less than $10.8 \%$ to obtain the optimum engineering results. This also confirms that the weaker materials such as claystones can also be used as embankment materials if the illite content is minimal (i.e. below $10.8 \%$ ).

Based on statistical analysis, the changes in illite content contribute $18 \%$ and the changes in water content contribute $34 \%$ to changes in the mechanical properties of claystone. The illite content does not directly contribute to changes in mechanical properties, but the illite structure (2:1) allows physical properties of mineral to change fast, due to its water absorbing capacity. The water absorption process inhibits change in mechanical properties of minerals. Therefore mineralogical studies, especially microstructures of clays, has great significance in the engineering projects.

Acknowledgements The authors would like to thank the management of PT Borneo Indobara, Indonesia, for supporting this research and allowing the publication of these results. Thanks are also due to RKDU Unpad 2017-2018 for supporting paper management and facilitating its publication.

\section{References}

[1] Plé, O., Manicacci, A., Gourc, J.-P., Camp, S., Flexural behavior of a clay layer: Experimental and numerical study. Can. Geotech. J., 2012, vol. 49(4), 485-493.

[2] Tiwari, B., Marui, H, Influences of clay mineralogy in residual shear strength of soil. Ann. Rep. of Res. Inst. for Hazards in Snowy Areas in Niigata Univ., 2002, vol. 24, 37-56.

[3] Supandi, Zakaria, Z., Sukiyah, E., Sudradjat, A., The correlation of exposure time and claystone properties at the Warukin Formation Indonesia. International Journal of Geomate, 2018, vol. 15 (52), 188-195.

[4] Benac, C., Oštrić, M., Jovančević, S.D., Geotechnical properties in relation to grain-size and mineral composition: The Grohovo landslide case study (Croatia). Geol. Croat., 2013, vol. 67(2), 127-136.
[5] Bayesteh, H., Mirghasemi, A.A., Numerical simulation of pore fluid characteristic effect on the volume change behavior of montmorillonite clays. Comput. Geotech., 2013, vol. 48, 146155.

[6] Tembe, S., Lockner, D.A., Wong, T.-F., Effect of clay content and mineralogy on frictional sliding behavior of simulated gouges: Binary and ternary mixtures of quartz, illite, and montmorillonite. J. Geophys. Res. Sol. Ea., 2010, vol. 115, 22 p.

[7] Sakr, M.A., Shahin, M.A., Metwally, Y.M., Utilization of lime for stabilizing soft clay soil of high organic content. Geotechn. Geol. Eng., 2008, vol. 27, 105.

[8] Spagnoli, G., Fernandez-Steeger, T., Feinendegen, M., Stanjek, H., Azzam, R., The influence of the dielectric constant and electrolyte concentration of the pore fluids on the undrained shear strength of smectite. Soils Found., 2010, vol. 50(5), 757-763.

[9] Sherwood, P., Soil Stabilization with Cement and Lime. TSO, London, 1993.

[10] Al-Rawas, A.A., Mohamedzein, Y.E.A., Al-Shabibi, A.S., AlKatheiri, S., Sand-attapulgite clay mixtures as a landfill liner. Geotechn. Geol. Eng., 2006, vol.24, 1365-1383.

[11] Bell, F.G, Lime stabilization of clay minerals and soils. Eng. Geol., 1996, vol. 42(4), 223-237.

[12] Plé, O., Tourabi, A., Abuaisha, M.S., 3-Dimensional digital image correlation for strains determination in clayey soil. Appl. Mech. Mater., 2013, vol. 353, 463-466.

[13] Dimitrova, R.S., Yanful, E.K., Factors affecting the shear strength of mine tailings/clay mixtures with varying clay content and clay mineralogy. Eng. Geol., 2012, vol. 125, 11-25.

[14] Yu, C.Y., Chow, J.K., Wang, Y.-H., Pore-size changes and responses of kaolinite with different structures subject to consolidation and shearing. Eng. Geol., 2006, vol. 202, 122-131.

[15] Cosenza, P., Prêt, D., Giraud, A., Hedan, S., Effect of the local clay distribution on the effective elastic properties of shales. Mech. Mater., 2015, vol. 84, 55-74.

[16] Yao, Q.-L., Zhang, F.-T., Ding, X.-L., Zhang, L., Jiang, G., Experimental research on instability mechanism of silty mudstone roofs under action of water and its application. Proc. Earth Planetary Sci., 2009, vol. 1(1), 402-408.

[17] Gumaste, S.D., lyer, K.R., Sharma, S., Channabasavaraj, W., Singh, D.N., Simulation of fabric in sedimented clays. Appl. Clay Sci., 2014, vol. 91-92, 117-126.

[18] Wang, J., Guo, L., Cai, Y., Xu, C., Gu, C, Strain and pore pressure development on soft marine clay in triaxial tests with a large number of cycles. Ocean Eng., 2013, vol. 74, 125-132.

[19] Zhou, J., Gong, X., Strain degradation of saturated clay under cyclic loading. Can. Geotechn. J., 2001, vol. 38, 208-212.

[20] ASTM D2850-95, Standard Test Method for UnconsolidatedUndrained Triaxial Compression Test on Cohesive Soils, ASTM International, United States, 1999.

[21] Guilford, J.P., Fundamental Statistics in Psychology and Education. McGraw Hill, New York, 1956.

[22] Plé, O., Lê, T.N.H., Effect of polypropylene fiber-reinforcement on the mechanical behavior of silty clay. Geotext. Geomembr., 2012, vol. 32, 111-116. 